\title{
Assessing Entrepreneurship Education for Skill Acquisition and Job Generation by Business Education Students in Bayelsa State, Nigeria
}

\author{
Igbongidi Binaebi Paul \\ Department of Vocational and Technology Education, Niger Delta University, Wilberforce Island, Nigeria
}

Email address:

pauligbongidi@gmail.com

To cite this article:

Igbongidi Binaebi Paul, Assessing Entrepreneurship Education for Skill Acquisition and Job Generation by Business Education Students in Bayelsa State, Nigeria. International Journal of Education, Culture and Society. Vol. 2, No. 1, 2017, pp. 1-5.

doi: $10.11648 /$ j.ijecs.20170201.11

Received: December 30, 2016; Accepted: January 14, 2017; Published: February 16, 2017

\begin{abstract}
The major purpose of this study is to examine the assessment of entrepreneurship education for skill acquisition and job generation by business education students in Bayelsa State, Nigeria. This study adopted a survey design because the study sought to determine the opinion of the respondent on Assessment of Entrepreneurship Education for Skill Acquisition and Job Generation by Business Education Students in Bayelsa State, Nigeria. The population of this study consists of all three and four hundred level business education students in the Department of Vocational and Technology Education in Bayelsa State. The sample size for the study was one hundred and twenty-five (125) students representing $45 \%$ of the population. The proportionate stratified random sampling technique was used in drawing the sample for the entire population and which is considered to be representative of the whole population. Based on the findings, the following recommendations are proffered: The youths should be properly encouraged to become entrepreneurs through implementation of relevant policies, in order to forestall the problem of graduate unemployment in the region; The National Directorate of Employment (NDE) should intensify effort to re-orient unemployed graduate on the benefits of not solely relying on Government for paid jobs.
\end{abstract}

Keywords: Entrepreneurship Education, Skill Acquisition, Job Creation, Business Education

\section{Introduction}

Entrepreneurship as a concept evolved many centuries ago and it has formed the basis for economic growth and development. It has been defined in different ways by various people.

Entrepreneurship education refers to programmes that promote and provide skill training for business generation and development [1]. Also, Alberti, Sciascia and Poli [2] define entrepreneurship education as the structured formal conveyance of entrepreneurship competencies which in turn refers to the concepts, skills and mental awareness used by individuals during the process of starting and developing their growth oriented ventures. Another view of entrepreneurship education is the term given to someone who has innovative ideas and transforms them to profitable activities [3]. Entrepreneurship education is the type of education which has the ability to impact on the growth and development of an enterprise through technical and vocational training [4]. According Atakpa [5], entrepreneurship is the aspect of education which equips an individual and creates in the person the mindset to undertake the risk of venturing into something new by applying the knowledge and skills acquired in school. Still, to Fashua [6], entrepreneurship education creates the willingness and ability in a person to seek out investment opportunities in the society and be able to establish and run an enterprise successfully based on the identified opportunities. This means that entrepreneurship education helps to provide business education students with the knowledge, skills and innovation to encourage entrepreneurship in variety settings.

Entrepreneurship education particularly in Nigeria is structured to achieve the following objectives according to Paul [7];

1. To offer functional education for the youths so as to enable them to be self-employed and self reliant.

2. To offer graduates with adequate training that will 
enable them to be creative and innovative in identifying novel business opportunities.

3. To provide university/colleges graduates with adequate training in risk management to make certainty bearing feasible.

4. To provide the young graduates with enough training and support that will enable them to establish a career in small and medium sized businesses.

5. To offer graduates adequate training in the acquisition of skills that will enable them meet the manpower needs of the society.

6. To stimulate both individual and economic growth of rural and less developed areas.

7. To provide both small and medium business enterprises with opportunity of recruiting graduates who are trained and tutored in the skills relevant to the management and operation of small businesses.

8. To inculcate the spirit of perseverance in the youths and adults which will enable them to persist in any business venture they embark on.

However, the extent to which a graduate can be expected to become more enterprising as a result of their entrepreneurship education will inevitably vary from person to person. It depends on the extent to which they demonstrate some or all of the following; personal skills, attributes, behavioural and motivational capacities which can be used in any context (social, work, leisure etc). Prominent by these are: intuitive decision-making, capacity to make things happen autonomously, networking, initiative taking, opportunity identification, creative problem-solving, strategic thinking, self-efficacy, ability to cope with ambiguity) and having empathy with entrepreneurial ways of doing, thinking, feeling, communicating, organizing and learning. Skill does not depend solely upon a person's fundamental, innate capacities but must be developed through training, practice and experience an individual acquired. Skill according to Bolt-Lee and Foster [8] is the art of possessing the ability to power, authority, or competency etc. to do the task required of an individual on the job. Two fundamental issues are used when a skill is to be acquired. According to Okoro and Ursula [9], the first is the conditions which promote acquisition and the second is the change that will occur when the skill is acquired.

However, when an individual set out to learn a new skill, he usually starts with a communicable programme of instruction. Good learners do not jump into an operation without first receiving the necessary verbal instruction. Thus the instruction given in bits, units modules in stages, perhaps must be fused together to form a skilled performance.

There are many processes of acquisition and development in achieving entrepreneurial skills. Pleshette in Okoro and Ursula [9] outlined the four main stages of acquisition and development of entrepreneurial skills to include:

- Analyze and identify the current and foreseeable skill needs to business, in terms of management, administrative and technical skills and relative importance of these.
- Identify the entrepreneur's own personal goals, objectives and analyze and evaluate his/her own skills and resources in relation to these.

- Produce a realistic personal development plan for the potential entrepreneur.

- Monitor on-going performance on follow-up of the entrepreneur once the business has started and progress made towards developing the new skills that had been previously identified as necessary for the success of the business.

\subsection{Statement of the Problem}

Entrepreneurship education is a sort of intervention programme which was introduced into Nigeria's tertiary education sub-sector in 2006 to remedy the unemployment challenge; and redirect the attention of our youths/graduates towards job generation by instilling in them relevant entrepreneurial skills that will positively grow and develop the economy. The goals and objectives of the programme seem laudable and for these goals and objectives to be achieved, some machinery has to be put in place. The relevance of this programme in the curriculum of all tertiary institutions in Nigeria is geared at creating an entrepreneurial culture and entrepreneurial spirits in the students.

It was against the background that the researchers intend to investigate the assessment of entrepreneurship education for skill acquisition and job generation by business education students.

\subsection{Purpose of the Study}

The major purpose of this study is to assess of entrepreneurship education for skill acquisition and job generation by business education students. Specifically, the study sought to:

i.) Examine the extent to which entrepreneurship education could contribute to acquisition of skills by business education students for job generation in Bayelsa State.

ii.) Assess the perceptions of business education students on entrepreneurship education as a tool for reducing unemployment by student in Bayelsa State.

iii.) Identify the strategies for enhancing entrepreneurship education for business education students in Bayelsa State.

\subsection{Research Questions}

The following research questions were formulated to guide this study;

i.) To what extent does entrepreneurship education contributes to acquisition of skills by business education students for job generation in Bayelsa State?

ii.) What is the perception of business education students on entrepreneurship education as a tool for reducing unemployment by student in Bayelsa State?

iii.) What are the strategies for enhancing entrepreneurship education for business education students in Bayelsa State? 


\section{Methodology}

\subsection{Research Design}

This study adopted a survey design because the study sought to determine the opinion of the respondents on Assessment of Entrepreneurship Education for Skill Acquisition and Job Generation by Business Education Students in Niger Delta Bayelsa State.

\subsection{Population of the Study}

The population of this study consists of all 106 three hundred level and 171 four hundred level business education students in the Department of Vocational and Technology Education of the Bayelsa State, Wilberforce Island. The population therefore was two hundred and seventy-seven.

Table 1. Population Distribution of three and four hundred level Business Education Students in the Department of Vocational and Technology Education.

\begin{tabular}{lll}
\hline Option & Year 3 & Year 4 \\
\hline Accounting education & 31 & 54 \\
Marketing education & 70 & 80 \\
Management & 1 & 30 \\
Office management technology & 4 & 4 \\
Total & 106 & 171 \\
\hline
\end{tabular}

\subsection{Sample and Sampling Techniques}

The sample size for the study was one hundred and twenty- five (125) students representing $45 \%$ of the population. The proportionate stratified random sampling technique was used in drawing the sample for the entire population and which is considered to be representative of the whole population.

\subsection{Instrumentation}

The instrument used in obtaining data for this study was self-constructed questionnaire titled 'Assessment of Entrepreneurship Education for Skill Acquisition and Job Generation by Business Education Students' (AEESAJCBES).

\subsection{Validity and Reliability of Instrument}

The instrument was face validated by three experts in business education and measurement and evaluation and was tested for reliability using Cronbach alpha formula and a reliability of 0.87 was obtained. The questionnaire items were rated using a four point likert scale and nominal values were assigned thus; Strongly Agree (4) Agree (3) Disagree (2) Strongly Disagree (1).

\subsection{Method of Data Analysis}

The data collected were analyzed using descriptive statistics of mean and standard deviation. The level of agreement with each questionnaire items was determined based on the midpoint for the scale, which is 2.50. Mean scores of 2.50 and above were taken as agreed while mean scores below 2.50 were taken as disagreed.

\subsection{Presentation of Results}

Table 2. Research Question One: To what extent does entrepreneurship education contribute to acquisition of skills by business education students in Bayelsa State?

Mean responses of the extent entrepreneurship education contribute to acquisition of skills by business education students in Bayelsa State.

\begin{tabular}{|c|c|c|c|c|}
\hline $\mathbf{S} / \mathbf{N}$ & Entrepreneurial Skills & $\mathbf{X}$ & S. D & Remarks \\
\hline 1. & Possessions of sound human relations skills have relevance in setting up entrepreneurship venture. & 3.55 & 0.45 & Agreed \\
\hline 2. & Managerial skills acquired have relevance in ensuring entrepreneurial success. & 3.38 & 0.62 & Agreed \\
\hline 3. & Accounting and financial competency skills have relevance in starting and managing a business venture. & 3.35 & 0.65 & Agreed \\
\hline 4. & $\begin{array}{l}\text { Marketing skills possessed as a result of entrepreneurship education has relevance in starting and managing a business } \\
\text { venture. }\end{array}$ & 3.2 & 0.8 & Agreed \\
\hline 5. & $\begin{array}{l}\text { Communication skills possessed as a result of entrepreneurship education has relevance in starting and managing a business } \\
\text { venture. }\end{array}$ & 3.16 & 0.84 & Agreed \\
\hline
\end{tabular}

Key: X = Mean, S. D = Standard Deviation

The data presented in the table above showed that all items have their mean values ranging from 3.20 to 3.55 indicating that all the respondents agreed that the items are ways entrepreneurship education contribute to acquisition of skills by business education students in Bayelsa State. The items had a standard deviation range of 0.84 to 0.45 which shows that the respondents were close together in their responses to each items and were not far from the mean.

Table 3. Research Question Two: what is the perception of business education students on entrepreneurship education as a tool for reducing unemployment by students in Bayelsa State?

Mean responses of the perception of business education students on entrepreneurship education as a tool for reducing unemployment by student in Bayelsa State.

\begin{tabular}{|c|c|c|c|c|}
\hline $\mathbf{S} / \mathbf{N}$ & Students Perception & $\mathbf{X}$ & S. D & Remarks \\
\hline 1. & Entrepreneurship education empowers student to face the challenge of unemployment after graduation. & 3.55 & 0.45 & Agreed \\
\hline 2. & Entrepreneurship education helps to reduce poverty. & 3.3 & 0.70 & Agreed \\
\hline 3. & Entrepreneurship education exposes students to the business world. & 3.5 & 0.50 & Agreed \\
\hline 4. & Entrepreneurship education enables students to be self reliant. & 3.61 & 0.39 & Agreed \\
\hline 5. & Entrepreneurship education helps to develop creativity and innovativeness in students. & 3.57 & 0.43 & Agreed \\
\hline
\end{tabular}


The data presented in the table above showed that all items have their mean value ranging from 3.30 to 3.61 indicating that all the respondents agreed that the items are perception of business education students on entrepreneurship education as a tool for reducing unemployment by student in Bayelsa State. The items had a standard deviation range of 0.70 to 0.39 which shows that the respondents were close together in their responses to each items and were not far from the mean.

Table 4. Research Question three: what are strategies for enhancing entrepreneurship education by business education student of Bayelsa State?

Mean responses of the strategies for enhancing entrepreneurship education by business education students of Bayelsa State.

\begin{tabular}{|c|c|c|c|c|}
\hline $\mathbf{S} / \mathbf{N}$ & Strategies & $\mathbf{X}$ & S. D & Remarks \\
\hline 1. & Provision of funds by government, financial institution and NGO's. & 3.55 & 0.45 & Agreed \\
\hline 2. & Provision of interest free loans to start up their own business. & 3.38 & 0.62 & Agreed \\
\hline 3. & Establishment of a center for Entrepreneurship development. & 3.35 & 0.65 & Agreed \\
\hline 4. & Provision of conducive environment and facilities for the teaching and learning of entrepreneurship studies. & 3.2 & 0.80 & Agreed \\
\hline 5. & Installing educational training and development programme. & 3.16 & 0.84 & Agreed \\
\hline
\end{tabular}

The data presented in the table above showed that all items have their mean value ranging from 3.16 to 3.55 indicating that all the respondents agreed that the items are strategies for enhancing entrepreneurship education by business education students of Bayelsa State. The items had a standard deviation range of 0.84 to 0.45 which shows that the respondents were close together in their responses to each items and were not far from the mean.

\subsection{Discussion of Findings}

In table 1, all the five items items were accepted as ways entrepreneurship education contribute to acquisition of skills by business education students in Bayelsa State Bayelsa state because all the items met the benchmark mean of 2.5 and above. This finding was in line Ekwue [10] who listed the following as skills required in entrepreneurship: human relationship, marketing, finance, accounting, management, control, negotiation, venture, launch and managing growth.

In table 2, all the five items were accepted as perception of business education students on entrepreneurship education as a tool for reducing unemployment by student in Bayelsa State, Bayelsa state. This is in consonance with the previous findings of Kolvereid and Moen, [11]; Owusu-Ansah, [12]; Uduak and Aniefiok, [13] that entrepreneurship education helps graduates to acquire increase understanding of entrepreneurship and equip them with skills relevant for job generation. The study evidence shows that entrepreneurship education creates inspiring awareness to business opportunity, provides exposure to entrepreneurship process. Builds self confidence, equip graduates with knowledge and skills and engender self-employment as an alternative career option ([13], [14]; [15]; [16]).

In table 3, all the five items were accepted as strategies for enhancing entrepreneurship education by business education students in Bayelsa state. This finding is line with Okoro and Ursula [9], who outlined provision of funds by government, financial institution and NGO's; provision of interest free loans to start up their own business; establishment of a center for Entrepreneurship development; provision of conducive environment and facilities for the teaching and learning of entrepreneurship studies and installing educational training and development programme as strategies for promoting entrepreneurship education.

\section{Conclusion}

Based on the study it can be concluded that entrepreneurship can reduce unemployment among business education students in Niger Delta university, Bayelsa State, Nigeria.

\section{Recommendations}

Based on the findings, the following recommendations are proffered.

(1) The youths should be properly encouraged to become entrepreneurs through implementation of relevant policies, in order to forestall the problem of graduate unemployment in the region.

(2) The National Directorate of Employment (NDE) should intensify effort to re-orient unemployed graduates on the benefits of not solely relying on Government for paid jobs.

(3) The National Poverty Eradication Programme (NAPEP) should as a matter of serious concern make funds available to all the registered graduates of Entrepreneurship education to set up their business enterprises.

(4) The enterprise college set up by the government should enroll graduates of Entrepreneurship education for them in order to acquire practical skills.

\section{Acknowledgement}

The authors wish to thank the students in the Department of Vocational and Technology Education who served as respondents and also to the reviewer of this work for his corrections and suggestions.

\section{References}

[1] Vesper, K. H. (1990). New venture strategies. New York Prentice-Hall Eaglewood Cliffs.

[2] Alberti, F., Sciscia, S. and Poli, A. (2004). 'Entrepreneurship Education; Notes on an ongoing debate'. Proceedings of the 14th Annual International Entrepreneur Conference, University of Napoli Federico 11, Italy, 4-7 July. 
[3] Omolayo, B. (2006). 'Entrepreneurship in theory and practice'. Ado-Ekiti, UMAD Press.

[4] Tamuno, S. O \& Ogiji, P (1999). The Development of Entrepreneurial Education in Nigeria. Journal of Education in Developing Areas XIII, 140-149.

[5] Atakpa, R. A. (2011). Entrepreneurship education: A Sine Qua-non in Business Education in Nigeria. Business Education Journal 1 (11), 1-6.

[6] Fashua, K. O. (2006). Entrepreneurship Theory, Strategies and Practice. Abuja: Bee Publishers.

[7] Paul, E. O. (2005). Entrepreneurship education. In P. M. Ezema, E. O. Paul, B. O. Anioke, G. A. G. Okwuolisa, I. A. Eheli and H. U. Anih (Eds). Entrepreneurship in vocational education. Enugu: OZYBEL Publishers.

[8] Bolt lee, C and Foster, S. (2003). The core competency framework: A new element in continuing call for accounting education change in the United States. Accounting Education, $12(1), 33-47$

[9] Okoro, I. F and Ursula, O. I. (2012). The teacher and skills acquisition at basic education from the perspective of cake making in home economics. International journal of the common wealth research and capacity education initiative (IJCWRCEI) Volume 3 No 3.
[10] Ekwue, K. C (2008). Rating of Accounting Skills needed for Management of Small Business by Entrepreneurs. Business Education journal 4 (2) Endogenous Regional Growth. Journal of Entrepreneurship and Regional Development, 12.

[11] Kolvereid L and Moen O (1997). Entrepreneurship by Business Graduates: Does a major in Entrepreneurship Make a Difference? J. Euro. Industrial Training, 21 (4): 154.

[12] Owusu-Ansah W. A. (2004). The impact of entrepreneurship education on career intentions and aspirations of tertiary students in Ghana. A paper presented at the World Conference of International Council for Small Business, 20th - 23rd June 2004, Johannesburg, South Africa.

[13] Uduak J. E, Aniefiok O. E. (2011). Entrepreneurship education and career intentions of tertiary education students in Akwa Ibom and Cross River States, Nigeria. J. Int. Edu. Studies, 4 (1): 172-178.

[14] Oyelola O (2010). Entrepreneurship education: Key to solving graduate Unemployment. Vanguard, August 13, 2010.

[15] Arogundade B. B. (2011). Entrepreneurship Education. An Imperative for Sustainable Development in Nigeria, J. Emerging trends in Edu. Res. Policy Studies, 2 (1): 26-29.

[16] Bassey UU, Olu D (2008). Tertiary Education and Graduate self-Employment Potentials in Nigeria. J. world University Forum, 1 (3): 31-42. 